原著

\title{
脳動脈瘤クリッピング術の技量の継承
}

\author{
出井 勝, ${ }^{1,2}$ 山根 冠児 ${ }^{1}$, 沖田 進司 $^{1}$ \\ 熊野 潔, 中江 竜太 $^{1}$
}

\section{A Method of Handing down Surgical Clipping Technique for Cerebral Aneurysm}

\author{
Masaru IdeI, M.D., ${ }^{1,2}$ Kanji Yamane, M.D., ${ }^{1}$ Shinji OKITA, M.D., ${ }^{1}$ Kiyoshi Kumano, M.D., ${ }^{1}$ \\ and Ryuta NAKAE, M.D. ${ }^{1}$ \\ ${ }^{1}$ Department of Neurosurgery, Chugoku Rosai Hospital, Kure, and ${ }^{2}$ Department of \\ Neurosurgery, University of Occupational and Environmental Health, School of Medicine, \\ Kitakyushu, Japan
}

Summary: Meticulous clipping techniques are essential to obtain good results. Recently, the introduction of intravascular surgery for cerebral aneurysms has decreased the number of the direct clipping surgeries. And the increasing number of the lawsuits against doctors further discourages young surgeons from attempting clipping. As a result, young neurosurgeons, have less experience performing clipping. Therefore, we must learn clipping techniques from expert neurosurgeons under the limitation of having fewer opportunities to perform clipping surgery. In this paper, I present my experiences and discuss ways to obtain techniques for clipping surgery.

I performed surgical clipping in 19 cases, 12 unruptured and 7 ruptured aneurysms, 7 males and 12 females aged from 36 to 79 years old (mean 61.9 years). Postoperatively, there were no symptomatic complications, but there were 2 asymptomatic infarctions that were revealed on CT scan. Intraoperative premature rupture occurred in 1 patient with a ruptured aneurysm.

Techniques of manipulation with micro-forceps, suction and spatula are required for successful clipping. Off-the-job training of dissecting chicken wing arteries and rat abdominal aortas and vena cavas is useful. Moreover, actual experiences of surgical operations are essential. Surgical experiences raise the motivation of young neurosurgeons and encourage them to train more. We believe that this benign cycle contributes to meticulous surgical skills.

\author{
Key words: \\ - cerebral aneurysm \\ - clipping \\ - benign cycle \\ - experience \\ - surgical skill
}

Surg Cereb Stroke (Jpn) 37: 192-196, 2009
はじめに

さまざまな分野において技量の継承問題が取り上げられ ているが，医療界も例外ではない．特に手術難易度の高い
脳神経外科領域では, 各種学会においてさかんに手術トレ 一ニング, 手術教育が議論され, 技量の継承が学会の主題 としても取り上げられている5).そこで今回われわれは, 脳神経外科手術の中で，血管内治療の発達に伴い技量の継

\footnotetext{
${ }^{1}$ 中国労災病院 脳神経外科, ${ }^{2}$ 産業医科大学 脳神経外科(受稿日 2008.10.14)(脱稿日 2009.1.13)〔連絡先： ₹807-8555 福岡県北九州 市八幡西区医生ヶ丘 1-1 産業医科大学 脳神経外科 出井 勝] [Address correspondence: Masaru IDEI, M.D., Department of Neurosurgery, University of Occupational and Environmental Health, School of Medicine, 1-1 Iseigaoka, Yahatanishi-ku, Kitakyushu, 807-8555, Japan]
} 
Table 1 A summary of the cases who underwent clipping operations

\begin{tabular}{|c|c|c|c|c|c|}
\hline Case & Age/ Sex & Location/ Side & SAH (H\&K grade) & Problem & $\mathrm{mRS}$ \\
\hline 1 & $79 / F$ & $A C A / R$ & - & & 0 \\
\hline 2 & $64 / F$ & $M C A / R$ & - & & 0 \\
\hline 3 & $59 / F$ & IC $-A c h / R$ & - & & 0 \\
\hline 4 & $69 / F$ & $D-A C A / R$ & - & & 0 \\
\hline 5 & $70 / F$ & $\mathrm{MCA} / \mathrm{L}$ & - & & 0 \\
\hline 6 & $75 / M$ & $M C A / R$ & - & & 0 \\
\hline 7 & $58 / F$ & $\mathrm{MCA} / \mathrm{L}$ & - & & 0 \\
\hline 8 & $36 / M$ & A-com & - & & 0 \\
\hline 9 & $67 / M$ & $\mathrm{MCA} / \mathrm{L}$ & - & & 0 \\
\hline 10 & $65 / M$ & A-com & - & & 0 \\
\hline 11 & $67 / F$ & IC $-A c h / L$ & - & & 0 \\
\hline 12 & $51 / M$ & A-com & - & & 0 \\
\hline 13 & $41 / M$ & A-com & $+(1)$ & & 0 \\
\hline 14 & $54 / M$ & A-com & $+(\|)$ & & 3 \\
\hline 15 & $47 / F$ & IC $-P C / L$ & $+(\|)$ & & 0 \\
\hline 16 & $76 / F$ & $\mathrm{IC} \cdot \mathrm{PC} / \mathrm{R}$ & $+(I I I)$ & premature rupture & 6 \\
\hline 17 & $78 / F$ & IC -PC / L & $+(\mathrm{IV})$ & & 4 \\
\hline 18 & $48 / F$ & A-com & $+(\|)$ & infarction (Heubner a.) & 0 \\
\hline 19 & $73 / F$ & A-com & $+(I I I)$ & & 2 \\
\hline
\end{tabular}

$\mathrm{SAH}$; subarachnoid hemorrhage, H\&K grade; Hunt \& Kosnik grade, mRS: modified Rankin scale, F; female, $M$; male, ACA; anterior cerebral artery, MCA; middle cerebral artery, IC - Ach; internal carotid artery-anterior choroidal artery, D-ACA; distal-anterior cerebral artery, A-com; anterior-communicating artery, IC -PC; internal carotid artery-posterior communicating artery, R; right, L; left

承がますます困難となることが予想される脳動脈瘤クリッ ピング術に注目し, 技量を継承するためにはどうすべきか, 自身のクリッピング経験を振り返り初心者の立場から意見 を述べる。

\section{対象および方法}

対象は筆者が初クリッピングから今までに経験した連続 19 動脈瘤 (未破裂 12 例, 破裂 7 例) である. 男性 7 例, 女 性 12 例，平均年齢 61.9 歳であった。術中生じたトラブル， 合併症，予後につき検討した。

\section{結果}

全症例の要約を Table 1 に提示する。部位は前交通動脈 瘤 8 例, 中大脳動脈瘤 5 例, 内颈動脈瘤 5 例, 未梢性前大 脳動脈㾿 1 例であった。術中のトラブルとしては, 破裂内 頚動脈瘤症例で 1 例に premature rupture を生じ, 破裂前 交通動脈瘤症例で 1 例に disorientation を生じた。合併症 では無症候であったものの CTで確認した脳梗塞を2例 (10.5\%)に認めた Fig. 1)．1例は症例 1 でクリップの rota-

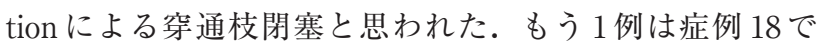
術中の脳圧排による Heubner artery の閉塞が原因と考え られた。予後については未破裂動脈瘤症例では全例で mRS (modified Rankin scale);0を保っていたが, 破裂例
は術前の状態がさまざまであり退院時の mRS で $2,3,4,6$ がそれぞれ 1 例，mRS; 0 が3例であった。

\section{代表 症 例}

〈症例 13〉41歳, 男性. 突然の頭痛を発症し近医で施行 された頭部 CTでくも膜下出血を認め当科紹介となる. 脳 血管造影検査で前交通動脈瘤を認めた。lt pterional approachによりクリッピング術を行うこととした。術中 左 A1，A2 剝離し動脈瘤を同定する予定であったが動 脈瘤がなく disorientationを生じてしまった。術前の右内 頚動脈撮影では対側澒動脈の圧迫撮影時のみ描出される破 格血管(前交通動脈から分岐した左 orbito-frontal artery) を見落とし，その血管を左 A2 と誤認していたことにより 生じた問題であった(Fig. 2). そのことを指導医に指摘さ れ orientationをつけることで最終的にはクリッピングを 行うことができた。第 28 病日, 神経症状なく退院した。

〈症例 16〉76歳, 女性. 頭痛, 嘔吐を発症し当院へ救急 搬送となる. 頭部 CT でくも膜下出血を認め入院. 右動眼 神経麻疩, 項部硬直を認めた。脳血管造影検查で右内澒動 脈後交通動脈分岐部動脈瘤を認めた。 lt pterional approachでクリッピングを行うこととした。動脈瘤の䅡 部を確保する際 premature rupture を生じた。指導医によ る pin point suctionのもと内澒動脈近位部に temporary 

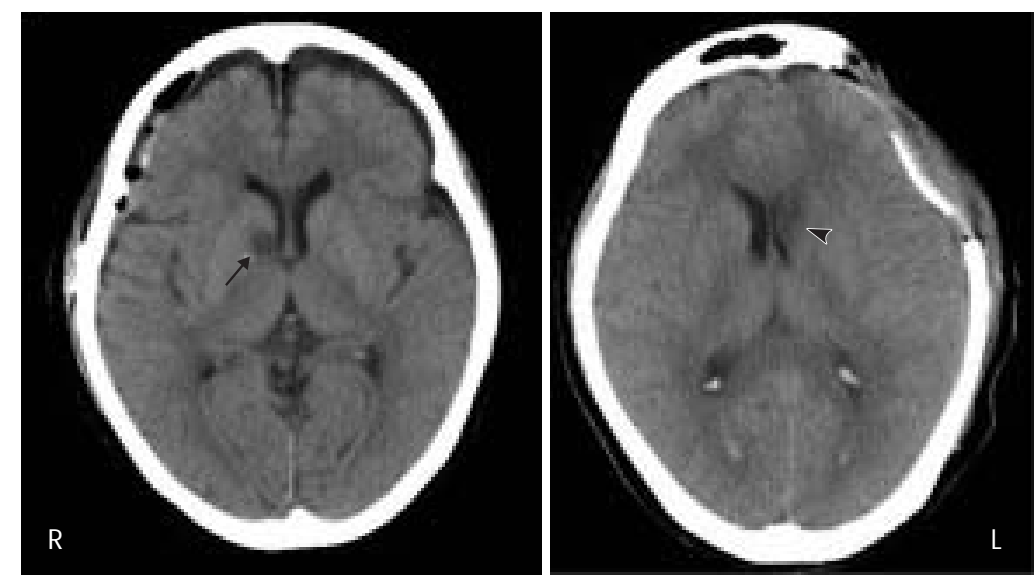

A $\mid B$

Fig. 1 Case 1, Case 18. Postoperative CT scan shows small infarction in the right caudate head in case 1 ( $A$, arrow) and in the left caudate head in case 18 (B, arrowhead).
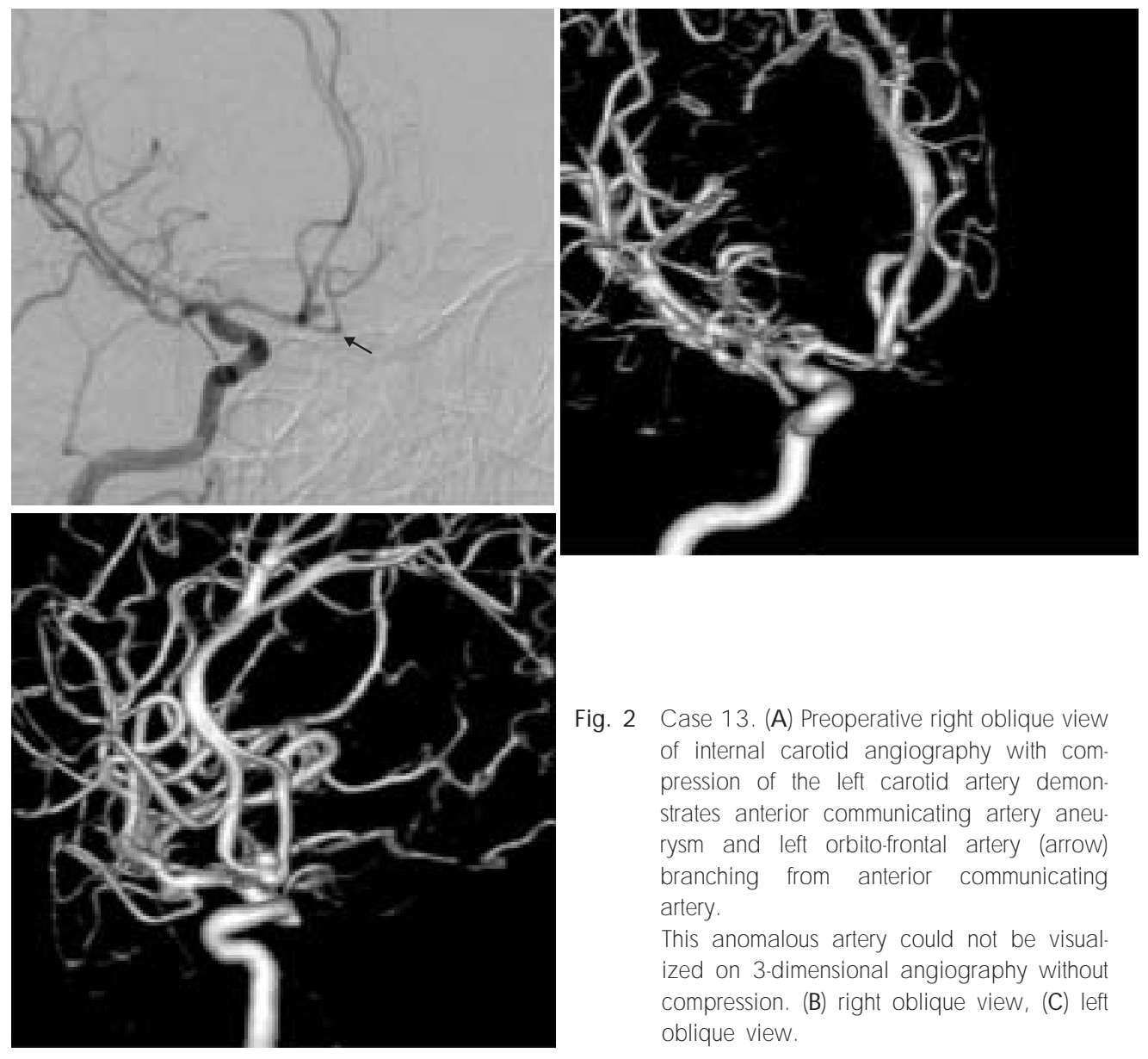

Fig. 2 Case 13. (A) Preoperative right oblique view of internal carotid angiography with compression of the left carotid artery demonstrates anterior communicating artery aneu$\frac{A \mid B}{C}$ rysm and left orbito-frontal artery (arrow) branching from anterior communicating artery.

This anomalous artery could not be visualized on 3-dimensional angiography without compression. (B) right oblique view, (C) left oblique view.

clip にて一時的血流遮断を行い動脈瘤頚部を確保しクリッ ピングを行うことができた。その後著明な脳血管攣縮によ り脳梗塞が生じ，第 13 病日に死亡した。

\section{考察}

今回の結果だけをみると手術により症候を呈した合併症
はなかったが，術後の頭部 CT で脳梗塞と思われる所見を 2 例 $(10.5 \%)$ に認めた。術後ビデオを見返すと 1 例はクリ ップヘッドが頭蓋底に接触する形でクリッピングされてお り脳の戻りとともにクリップに rotation がかかったことに よる穿通枝閉塞が原因と考えられた.クリップ挿入方向や クリップ型の選択を工夫することが必要であったものと思 
われた。もう 1 例は脳へらによる前頭葉への圧排が強くか つ時間が長かったために生じた Heubner artery の閉塞と 思われた.シルビウス裂を大きく展開し顕微鏡の視軸をよ り頭蓋底方向からにすることや脳へらによる圧排を間歇的 に行うなどの工夫が必要であったものと思われた。これら の脳梗塞は初心者がクリッピングを行ったときに特有のも のではないが，エキスパートであれば防ぐことができた可 能性はある ${ }^{6)}$ 。こうした問題がある症例からこそ学ぶべき ことは多く，十分な反省をすることにより次の成功に繋が るものと思われる．また，振り返ってみると術中だけでは なく術前にも反省すべき点があった．症例 13 で術前の血 管造影検查結果の読影不足のため前交通動脈から分岐する 破格血管を見落とし，術中 disorientation を起こしてしま った。指導医によりそれを指摘されたため修正することは 可能であったが，筆者が初心者であるために生じた問題で ある。

症例 16 で経験した術中破裂は指導医がいなければ出血 のコントロールは困難であった。指導医の pin point suctionのもと指示を受けながらクリップすることができた. その場に打ける緊張感, 焦燥感と, premature ruptureを 生じたときの対処法はけっして off the job trainingでは経 験することのできないきわめて貴重な経験となった。

このように初心者はさまざまな問題に遭遇する可能性が 高く，またその処理能力も十分ではない．したがって，手 術に臨むにあたっては，初心者であることを十分自覚しけ っして指導医の指示を無視するようなことがあってはなら ず，もし指示に疑問があればその疑問点を述べ指導医の指 示を得るべきであると思われる。

指導医にとっては自ら手術を行ったほうが治療成績もよ く手術時間も短いにもかかわらず手術指導のためにあえて 下級医に手術を経験させなくてはならないといったジレン マがある．指導を受ける者はそのことを十分認識したうえ で手術に臨むべきである。また，麻酔科医，手術室ス夕ッ フに対しても多くの負担をかけることになる。それが容認 されるためには，日頃から手術に対する継続的な努力姿勢 を周囲のスタッフに示しておく必要がある ${ }^{4)}$ ．技量を獲得 するにしたがい上記問題が解消されていけば周囲から絶大 なる信頼をも得ることができるものと思われる。

脳動脈瘤クリッピング術において必要な技量とは何かを 考えると，マイクロ剪刀，吸引管，脳へら，これらの使用 技術の習得が必要であると思われる。なかでもマイクロ剪 刀は特に重要でありシルビウス裂の鋭的剝離，動脈瘤の 癒着の剝離など，欠くことはできず，その使用技術の習 得も容易ではない。ママイクロ剪刀の使用技術を習得するに はどうするべきかを考えると，まず off the job training と して手羽先の血管剝離，ラットの腹部大動脈，腹部大静
脈の剝離はシルビウス裂の鋭的剝離，動脈瘤の癒着の剝 離操作に近似しており良い練習環境を作ることができる。 しかし，似たような状況を作ることができてもまったく同 じ状況を作ることは不可能であり，最終的には on the job trainingつまり手術経験が必要となる。ところが，現在の 厳しい社会風潮の中では初心者が手術機会を与えられるこ とが困難になっている，そのような厳しいなかでも指導医 から手術機会を与えられるためにはどうすべきかを考える と, 高いモチベーションの維持, 十分な off the job training，指導医へのアピールが必要となると思われる．また， 教育を受ける真摰な姿勢を指導医に見せる必要があり，技 量を獲得したいという姿勢が指導医に伝わらなければ当然 実践の機会を与えられるはずがない，技量を持ちかつその 継承に理解のある指導医のもとで，日頃から高いモチべー ションを持ってくり返し off the job trainingを行えば自ず と手術機会を与えられるはずである。今回筆者が経験した 術中のトラブルの原因として, 技術の問題, 不適切な状況 判断があるが技術的問題についてはこのような on and off the job trainingによりある程度解決することができる。 しかし, off the job training で獲得するには限界のある判 断力の養成は初期教育で最も難しいともいわれてい $b^{4)}$. 適切な状況判断力を得るには指導医からのアドバイ 又を術中に得ることが最も効率的であると思われる。術中 トラブルを経験した 1 例 1 例を大切にし，今後同じような 状況に陥った場合どのようにするかを明確に考え，トラブ ルを繰り返さないようにしておくべきである。自ら専用の ノートを作り記載しておくのも 1 つの良い方法であると思 われる。

次に，現代における技量の継承問題はさまざまな分野に おいて取り上げられており，より大きな視点で技量の継承 について考えてみる。いわゆる団塊の世代の退職に伴い今 まで発展継承されてきた技術をもった職人たちが数多く去 ることとなり社会的問題となっている．わが国の製造業界 は，熟練技能の伝承という社会的な課題を抱えている ${ }^{2)}$. われわれが対象とするのは「もの」ではなく「人間」であ るという根本的な違いはあるが，われわれの世界にあては めてみると，技量を持った脳神経外科医は職人であり，脳 神経外科界のいわば貴重な人的資産ととらえることができ る.したがって，これらのエキスパートは若い世代に技量 を教育指導し継承していく使命があるのではなからうか. 優れた職人は，優れた教育者であるともいわれている2.

かつての職人技の伝承は言葉をもって手取り足取り教え るのではなく，あくまでも技術を見せるだけで，弟子は， 見よう見まねの反復練習 (一すなわち見習い一) を通して手 順や段取りを覚え，さらには仕事の全体像をも表象できる 能力を培うことが求められた ${ }^{2)}$. 


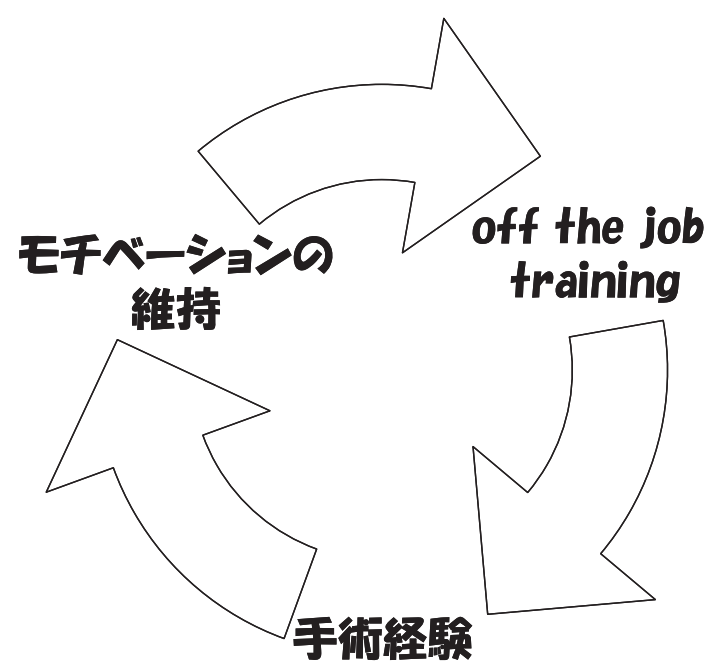

Fig. 3 This illustration shows the relation between the motivation, off-the-job training and surgical experiences. Their 3 reciprocal factors can form benign cycle for acquiring of the techniques of surgical clipping.

しかし, 対象が「人間」である手術においては, 経験に よって体得すべき技量を on the job training という形で獲 得するにはクリッピング経験数の少なくなった現状におい ては危険であり，技量が未熟なための合併症の発生につな がり，現在の社会では許容範囲を逸脱することになる．現 在われわれの抢かれている医療界は患者から高い水準の治 療成績が求められており，われわれの提供する手術技量の 質と信頼性はその高い水準になければならない，先人たち が技量を獲得, 発展させてきた時代と現在は大きく異なり, それをわれわれは認識しておく必要がある.

さらに動脈瘤に対し血管内治療が進歩し浸透してきてい ることからクリッピング症例は減少し，1人あたりのクリ ッピング経験数はますます減少すると考えられる．そのう え高い治療成績が求められるというジレンマに陥る。すべ ての動脈瘤が血管内治療で完全に治療可能となればクリッ ピングはなくなってもよい技術となる．しかし，クリッピ ングという技術は今のところ残ることが必要とされる技術 である ${ }^{1)}$.クリッピング手術数の減少が予想されることか らクリッピング技術の継承者数はかつてほど必要ないのか もしれない.このようなさまざまな問題がある状況の中で も継承する者となるためには少数のクリッピング技量継承 者の座を自ら勝ち取るという積極的姿勢が必要であると思 われる。

もし若いわれわれの世代が高い技量を継承することがで きなければどうなるであろうか.たとえばJET study (Japanese EC-IC Bypass Trial)を例にとる ${ }^{3)}$. studyに参 加した施設の術者はSTA-MCA (superficial temporal artery-middle cerebral artery) bypass術の高い技術を有 した者たちである。その高い技術により bypass術の有効 性をわが国から世界に発信することができた。もし，この 技量をわれわれの世代が継承することができなければ bypass術により救われる患者が存在しても手術をする脳 神経外科医がいないという状況に陥り, JET studyの成果 を役立たせることができなくなってしまう，そうならない ために先人たちが築いた技量を継承し 1 人でも多くの患者 を救うという使命をわれわれの世代は担っているものと思 われる。

技量を継承するにあたりモチベーションを保つことは欠 かせないと考えているが，モチベーションを高く維持する ことは容易ではない．われわれが脳神経外科医を志したと きにはなんらかの形で脳神経外科手術への憧れ，特に顕微 鏡手術への憧れを持っていたのではないか. この当初持っ ていた憧れこそがモチベーションにつながり，忙しい臨床

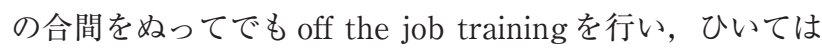
顕微鏡手術を経験することができるものと思われる，手術 経験を得ることでモチベーションをより高めることがで き，そしてさらに off the job trainingに励み，ますます手 術経験を積むことができるといういわば良循環を形成する ことができると思われる(Fig. 3)．この良循環をつくるこ とで先人たちが築いてきた技量を習得し継承することがで きるのではないかと筆者は考えている.

コイリングに比しクリッピング術の手技はほほ確立した ものといえるが, その手術方法, スタイルは施設間, 術者 により多種多様である．初心者はさまざまな手技を経験す ることにより，型にとらわれることなくよいと思われる技 術のみを獲得することもできる，継承するにとどまらず， さらに自身の技術を発達させることさえ可能であり，仕事 を創造する職人 ${ }^{2)}$ となることができると思われる.

本稿の要旨は第 37 回日本脳卒中の外科学会総会にて発 表した.

\section{文献}

1）石川達哉, 数又 研, 中山若樹, ほか：脳動脈瘤手術の expertを育てる教育はどのようにするか. 脳卒中の外科 35: $364-369,2007$

2）小関智弘：職人学. 講談社, 東京, 2003

3) JET Study Group: Japanese EC-IC Bypass Trial (JET Study)．脳卒中の外科 30: $97-100,2002$

4）堤 一生：私の手術教育一初心者指導の経験から一. 脳卒 中の外科 35: 361-363, 2007

5）第 37 回日本脳卒中の外科学会一脳卒中の外科：技量の継承 と新たな開発一, 2007

6） 中村一仁，石黒友也，池田英敏，ほか：未破裂動脈瘤クリ ッピング術の治療成績一脳動脈瘤手術初心者の経験一. 脳 卒中の外科 35: 370-375, 2007 